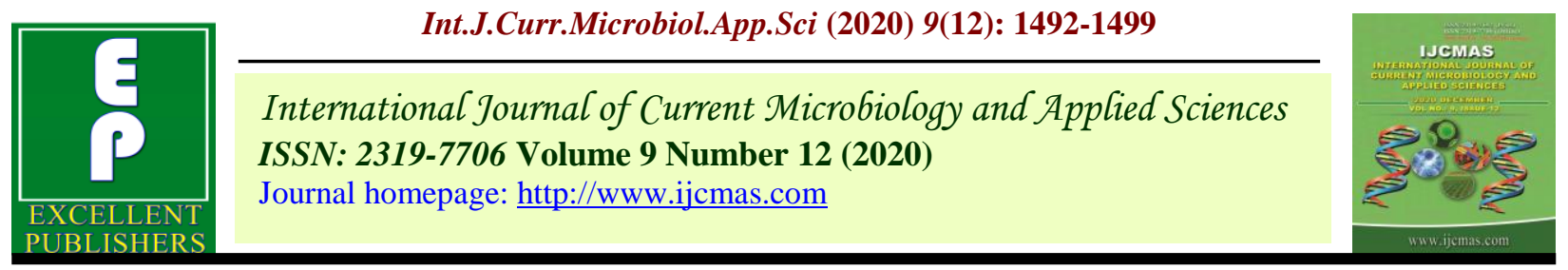

Original Research Article

https://doi.org/10.20546/ijcmas.2020.912.177

\title{
Effect of Phosphorus and Sulphur on Chlorophyll, Nodulation, Soil Properties and Optimum Dose of Phosphorus and Sulphur for Clusterbean [Cyamopsis tetragonoloba (L.) Taub]
}

\author{
Kiran Yadav ${ }^{*}$, S. R. Naga ${ }^{2}$, Shital Yadav ${ }^{3}$ and Basu Devi Yadav ${ }^{3}$ \\ ${ }^{1}$ Department of Soil Science and Agricultural Chemistry, College of Agriculture, \\ JAU, Junagadh, Gujarat, India \\ ${ }^{2}$ Department of Soil Science and Agricultural Chemistry, S.K.N. Agriculture University, \\ Jobner, Rajasthan, India \\ ${ }^{3}$ Department of Soil Science and Agricultural Chemistry, Swami Keshwanand Rajasthan \\ Agricultural University, Bikaner, Rajasthan, India \\ *Corresponding author
}

\section{A B S T R A C T}

\begin{tabular}{l} 
Ke y w o r d s \\
Clusterbean, \\
Phosphorus, \\
Sulphur, \\
Chlorophyll, \\
Nodules \\
\hline Article Info \\
$\begin{array}{l}\text { Accepted: } \\
12 \text { November } 2020 \\
\text { Available Online: } \\
10 \text { December } 2020\end{array}$ \\
\hline
\end{tabular}

\section{Introduction}

Clusterbean called as guar, is a draught tolerant annual legume crop. In India, clusterbean is grown for its green fodder and for the pods that are used as food and feed. Since it is a legume, it has soil enriching properties. The long deep tap root system enables the plant to grasp all the water available in the soil making it an ultimate drought resistant crop like other legumes and thus offer better scope for rainfed cropping
An experiment was conducted at Agronomy farm, S.K.N. College of Agriculture, Jobner, Jaipur during kharif, 2017. The experiment consisted 16 treatment combinations comprising of four levels each of phosphorus $\left(0,20,40\right.$ and $60 \mathrm{~kg} \mathrm{P}_{2} \mathrm{O}_{5}$ ha $\left.^{-1}\right)$ and sulphur $\left(0,20,40\right.$ and $\left.60 \mathrm{~kg} \mathrm{~S} \mathrm{ha}^{-1}\right)$ was laid out in randomized block design and replicated thrice. Clusterbean variety RGC-1038 was used as a test crop. The results indicated that total chlorophyll content at 45 DAS, number of total and effective root nodules at flowering were observed significantly maximum upto $40 \mathrm{~kg} \mathrm{P}_{2} \mathrm{O}_{5} \mathrm{ha}^{-1}$ level of phosphorus application over control and $20 \mathrm{~kg} \mathrm{P}_{2} \mathrm{O}_{5} \mathrm{ha}^{-1}$. Whereas, the available $\mathrm{N}, \mathrm{P}_{2} \mathrm{O}_{5}$ and $\mathrm{S}$ in soil after harvest of clusterbean were recorded significantly maximum with the application of $60 \mathrm{~kg} \mathrm{P}_{2} \mathrm{O}_{5} \mathrm{ha}^{-1}$. Application of sulphur upto $40 \mathrm{~kg} \mathrm{ha}^{-1}$ resulted in significantly maximum increase in total chlorophyll content at 45 DAS, number of total and effective root nodules at flowering over control and $20 \mathrm{~kg} \mathrm{~S} \mathrm{ha}^{-1}$. Where as, significantly maximum available $\mathrm{N}$, $\mathrm{P}_{2} \mathrm{O}_{5}$ and $\mathrm{S}$ in soil after harvest was recorded with the application of $60 \mathrm{~kg} \mathrm{~S} \mathrm{ha}{ }^{-1}$. The optimum dose of phosphorus and sulphur as derived from response function curve were 49.31 and $50.64 \mathrm{~kg} \mathrm{ha}^{-1}$ respectively. 
symbiosis with rhizobium bacteria. Indian soils are poor to medium in available phosphorus. Only about 30\% of the applied phosphorus is available to crops and remaining part converted into insoluble phosphorus. The beneficial effects of phosphorus on nodulation, growth and yield of legume crops have been well established because apart from important role in root development, phosphorus is necessary for growth of rhizobium bacterial, responsible for nitrogen fixation in nodules. Phosphorus application to legumes not only benefits the current crop but also favourably affects the succeeding non-legume crop. Sulphur is an important essential plant nutrient whose deficiency was identified in soils of semi-arid regions, especially in Jodhpur, Udaipur and Jaipur districts of Rajasthan (Tandon, 1986). Importance of sulphur in Indian agriculture is being increasingly emphasized and has a great impact on legume production. Sulphur also promotes nodulation in legumes and favours solubilization of organic nitrogen and there is decrease in the quantity of insoluble nitrogen. Although not a constitute, sulphur helps in chlorophyll formation. Sulphur application increases drought and cold tolerance in plant due to the process of disulphide linkage. It also helps in control of diseases and pests. Gypsum has been found as an equally effective and cheapest source of sulphur for most of the crops, as in India huge deposits of gypsum are available, especially in Rajasthan.

\section{Materials and Methods}

The present study was conducted at Agronomy Farm and the plant and soil samples were analysed in Department of Soil Science and Agricultural Chemistry, S.K.N. College of Agriculture, Jobner (Rajasthan) during the kharif season, 2017. The average rainfall of this region is about 400 to $500 \mathrm{~mm}$. The mean daily maximum and minimum temperatures during the growing crop season of clusterbean varied between 29.4 to 36.6 and 13.8 to 26.6 respectively. Similarly, mean daily relative humidity reached between 37 to $79 \%$. The soil of experimental site (before kharif 2017) was loamy sand in texture with soil $\mathrm{pH}$ 8.2. Five plants were randomly selected from each plot of every replication. Total number of nodules per plant was recorded at flowering on the basis of another five randomly selected plants from each net plot and uprooted carefully, the soil mass embodying the roots of the plant was washed off by water and total nodules were counted. The mean value was recorded as total number of nodules per plant. Number of effective nodules was counted from same plants as taken for total number of nodules. Healthy pink coloured nodules were counted and mean value was recorded as effective number of nodules per plant.

The chlorophyll content in leaves at 45 DAS was determined as per the method advocated by Arnon (1949) by taking $50 \mathrm{mg}$ fresh leaves; samples were homogenized in 80\% acetone and aliquat was centrifuged for 10 minutes at $2000 \mathrm{rpm}$ and the final volume was made to $10 \mathrm{ml}$. Absorbance of clear supernatant liquid was measured at $652 \mathrm{~nm}$ on spectronic-20.

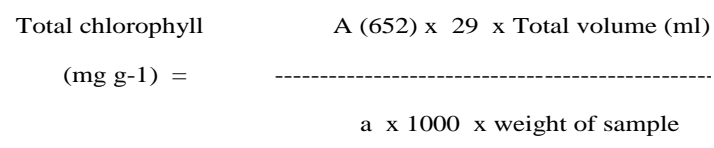

Where, $\mathrm{a}$ is the path length $=1 \mathrm{~cm}$.

Optimum dose of phosphorus and sulphur for yield of clusterbean under different phosphorus and sulphur levels will be worked out with the help of quadratic equation Croxton et al., (1973). To assess the fertility status of soil, the soil sample $(0-15 \mathrm{~cm}$ depth), from each plot at harvest of crop was taken. The samples were dried and passed through $2.0 \mathrm{~mm}$ plastic sieve to avoid metallic contamination for subsequent analysis and the samples were analysed as per standard methods. 


\section{Results and Discussion}

\section{Effect of phosphorus and sulphur on total chlorophyll content}

A perusal of data presented in table-1 revealed that increasing levels of phosphorus upto $40 \mathrm{~kg} \mathrm{P}_{2} \mathrm{O}_{5} \mathrm{ha}^{-1}$ significantly enhanced the total chlorophyll content at 45 DAS. Application of $40 \mathrm{~kg} \mathrm{P}_{2} \mathrm{O}_{5}$ ha-1 brought significant increase in total chlorophyll content at 45 DAS over control and $20 \mathrm{~kg}$ $\mathrm{P}_{2} \mathrm{O}_{5} \mathrm{ha}^{-1}$ by 13.86 and 6.48 percent, respectively. However, the application of 40 $\mathrm{kg} \mathrm{P}_{2} \mathrm{O}_{5} \mathrm{ha}^{-1}$ and $60 \mathrm{~kg} \mathrm{P}_{2} \mathrm{O}_{5}$ ha $^{-1}$ remained statistically at par with each other. Application of sulphur @ $40 \mathrm{~kg} \mathrm{ha}^{-1}$ significantly influenced the total chlorophyll content at 45 DAS over control and $20 \mathrm{~kg} \mathrm{~S}$ by 14.52 and 6.52 percent, respectively but it remained statistically at par with $60 \mathrm{~kg} \mathrm{~S} \mathrm{ha}^{-1}$.

Phosphorus is an essential constituent of all living organisms which play an important role in conservation and transfer of energy in metabolic reactions of living cells including biological energy transformations. The increase in photosynthetic activity in plant led to overall development in terms of growth. Thus, phosphorus fertilization enhanced the photosynthesis and other metabolic processes in the plant which ultimately enhanced the growth in terms of plant height, number of branches per plant and total chlorophyll content. These results are in close conformity with those of Ayub et al., (2012) and Raiger et al., (2017).

Sulphur being a constituent of succinyl Coenzymes A which involved in chlorophyll formation and creates a balanced nutritional environment in the plant system in keeping the micronutrients physiologically active, has been very instrumental in increased chlorophyll synthesis in plant tissues. sulphur is one of the most important constituent of glutathione (glutamyl-cysteinyl-glycine) which though not a primary product of cellular metabolism, plays important role in detoxification of compounds, which are not favourable for growth. These findings are in close conformity with those of Kumar and Kumar (2013) and Raiger et al., (2017). The increase in plant height may be due to the beneficial effect of sulphur on the various metabolic activities and also play an important role in synthesis of sulphur containing amino acids, co-enzyme and increase in chlorophyll content and vitamins etc. in growing region and improving the photosynthetic activity ultimately enhancing cell division and there by resulting higher crop growth rate (Imsande, 1998).

\section{Effect of phosphorus and sulphur on nodulation}

\section{Total nodules}

Data given in table-1 revealed that the number of total nodules per plant at flowering was influenced significantly with increasing levels of phosphorus upto $40 \mathrm{~kg} \mathrm{P}_{2} \mathrm{O}_{5} \mathrm{ha}^{-1}$, which was found at par with $60 \mathrm{~kg} \quad \mathrm{P}_{2} \mathrm{O}_{5} \mathrm{ha}^{-1}$. Application of phosphorus @ $40 \mathrm{~kg} \mathrm{ha}^{-1}$ significantly increased the number of total nodules per plant by 22.30 and 13.31 percent over control and $20 \mathrm{~kg} \mathrm{P}_{2} \mathrm{O}_{5} \mathrm{ha}^{-1}$, respectively. Application of sulphur @ $40 \quad \mathrm{~kg} \mathrm{ha}^{-1}$ significantly increased the number of total nodules per plant by 16.22 and 6.70 percent over control and $20 \mathrm{~kg} \mathrm{~S} \mathrm{ha}^{-1}$ respectively.

\section{Effective nodules}

Data further showed in table-1 that application of $40 \mathrm{~kg} \quad \mathrm{P}_{2} \mathrm{O}_{5} \mathrm{ha}^{-1}$ recorded significant increase in number of effective nodules per plant by 19.21 and 7.83 percent over control and $20 \mathrm{~kg} \mathrm{P}_{2} \mathrm{O}_{5} \mathrm{ha}^{-1}$, respectively. Application of $40 \mathrm{~kg} \mathrm{~S} \mathrm{ha}^{-1}$ recorded significant increase in number of effective 
nodules per plant by 24.53 and 12.30 percent over control and $20 \mathrm{~kg} \mathrm{~S} \mathrm{ha}^{-1}$, respectively which was found statistically at par with 60 $\mathrm{kg} \mathrm{Sha}{ }^{-1}$.

Table.1 Effect of phosphorus and sulphur on total chlorophyll content at 45 DAS, number of total and effective root nodules per plant at flowering of clusterbean

\begin{tabular}{|l|c|c|c|}
\hline Treatments & $\begin{array}{c}\text { Total Chlorophyll } \\
\text { content }(\mathbf{m g} \mathbf{g})\end{array}$ & Total nodules & Effective root nodules \\
\hline Phosphorus $\left(\mathbf{P}_{\mathbf{2}} \mathbf{O}_{\mathbf{5}}\right)$ & 1.803 & & \\
\hline $\mathbf{P}_{\mathbf{0}}$ & 1.928 & 18.02 & 13.74 \\
\hline $\mathbf{P}_{\mathbf{2 0}}$ & 2.053 & 19.45 & 15.19 \\
\hline $\mathbf{P}_{\mathbf{4 0}}$ & 2.132 & 22.04 & 16.38 \\
\hline $\mathbf{P}_{\mathbf{6 0}}$ & 0.043 & 23.30 & 17.27 \\
\hline SEm \pm & 0.124 & 0.46 & 0.34 \\
\hline $\mathbf{C D}(\overline{\mathbf{P}}=\mathbf{0 . 0 5 \%})$ & & 1.32 & 0.98 \\
\hline Sulphur & 1.797 & & 13.41 \\
\hline $\mathbf{S}_{\mathbf{0}}$ & 1.932 & 18.61 & 14.87 \\
\hline $\mathbf{S}_{\mathbf{2 0}}$ & 2.058 & 20.27 & 16.70 \\
\hline $\mathbf{S}_{\mathbf{4 0}}$ & 2.129 & 21.63 & 17.60 \\
\hline $\mathbf{S}_{\mathbf{6 0}}$ & 0.043 & 22.30 & 0.34 \\
\hline $\mathbf{S E m} \pm$ & 0.124 & 0.46 & 0.98 \\
\hline $\mathbf{C D}(\overline{\mathbf{P}}=\mathbf{0 . 0 5 \%})$ & & 1.32 & \\
\hline
\end{tabular}

Table.2 Effect of phosphorus and sulphur on organic carbon and available $\mathrm{N}, \mathrm{P}_{2} \mathrm{O}_{5}, \mathrm{~K}_{2} \mathrm{O}$ and $\mathrm{S}$ in soil after harvest

\begin{tabular}{|l|c|c|c|c|c|}
\hline Treatments & $\begin{array}{c}\text { Organic } \\
\text { carbon (\%) }\end{array}$ & $\begin{array}{c}\text { Available N } \\
(\mathbf{k g} / \mathbf{h a})\end{array}$ & $\begin{array}{c}\text { Available } \mathbf{P}_{\mathbf{2}} \mathbf{O}_{\mathbf{5}} \\
(\mathbf{k g} / \mathbf{h a})\end{array}$ & $\begin{array}{c}\text { Available } \mathbf{K}_{\mathbf{2}} \mathbf{O} \\
(\mathbf{k g} / \mathbf{h a})\end{array}$ & $\begin{array}{c}\text { Available S } \\
(\mathbf{m g} / \mathbf{k g})\end{array}$ \\
\hline $\begin{array}{l}\text { Phosphorus } \\
\left(\mathbf{P}_{\mathbf{2}} \mathbf{O}_{\mathbf{5}}\right)\end{array}$ & & & & \\
\hline $\mathbf{P}_{\mathbf{0}}$ & 0.199 & 114.18 & 15.26 & 136.12 & 8.29 \\
\hline $\mathbf{P}_{\mathbf{2 0}}$ & 0.200 & 121.14 & 16.78 & 138.58 & 9.41 \\
\hline $\mathbf{P}_{\mathbf{4 0}}$ & 0.202 & 124.96 & 18.10 & 141.05 & 10.28 \\
\hline $\mathbf{P}_{\mathbf{6 0}}$ & 0.205 & 128.76 & 20.20 & 141.35 & 10.92 \\
\hline $\mathbf{S E m} \pm$ & 0.002 & 1.27 & 0.33 & 2.09 & 0.13 \\
\hline $\mathbf{C D}(\overline{\mathbf{P}}=\mathbf{0 . 0 5 \%})$ & $\mathrm{NS}$ & 3.67 & 0.96 & $\mathrm{NS}$ & 0.38 \\
\hline Sulphur & & & & & \\
\hline $\mathbf{S}_{\mathbf{0}}$ & 0.197 & 114.86 & 15.03 & 135.21 & 7.39 \\
\hline $\mathbf{S}_{\mathbf{2 0}}$ & 0.201 & 120.91 & 17.01 & 138.33 & 9.70 \\
\hline $\mathbf{S}_{\mathbf{4 0}}$ & 0.202 & 124.64 & 18.44 & 141.72 & 10.41 \\
\hline $\mathbf{S}_{\mathbf{6 0}}$ & 0.206 & 128.63 & 19.85 & 141.84 & 11.40 \\
\hline $\mathbf{S E m} \pm$ & 0.002 & 1.27 & 0.33 & 2.09 & 0.13 \\
\hline $\mathbf{C D}(\overline{\mathbf{P}}=\mathbf{0 . 0 5 \%})$ & $\mathrm{NS}$ & 3.67 & 0.96 & $\mathrm{NS}$ & 0.38 \\
\hline
\end{tabular}

NS $=$ Non significant 
Table.3 Seed yield ( $Y$ ) as a function of phosphorus fertilization $\left(Y=b_{0}+b_{1} X+b_{2} X^{2}\right)$

\begin{tabular}{|l|l|c|}
\hline S.No. & Study parameters & Phosphorus \\
\hline $\mathbf{1}$ & Partial regression coefficients & \\
\hline & $\mathrm{b}_{0}$ & 829.40 \\
\hline & $\mathrm{b}_{1}$ & 10.97 \\
\hline & $\mathrm{b}_{2}$ & -0.095 \\
\hline $\mathbf{2}$ & Coefficients of multiple correlation $(\mathrm{R})$ & 0.999 \\
\hline $\mathbf{3}$ & Optimum level of phosphorus $(\mathrm{kg} / \mathrm{ha})$ & 49.315 \\
\hline $\mathbf{4}$ & Yield at optimum level $(\mathrm{kg} / \mathrm{ha})$ & 1139.35 \\
\hline $\mathbf{5}$ & Response at optimum level $(\mathrm{kg} / \mathrm{ha})$ & 309.95 \\
\hline
\end{tabular}

* Significant at 5\% level of significance

Table.4 Seed yield (Y) as a function of sulphur fertilization ( $\left.Y=b_{0}+b_{1} X+b_{2} X^{2}\right)$

\begin{tabular}{|l|l|c|}
\hline S.No. & Study parameters & Sulphur \\
\hline $\mathbf{1}$ & Partial regression coefficients & \\
\hline & $\mathrm{b}_{0}$ & 775.65 \\
\hline & $\mathrm{b}_{1}$ & 15.3075 \\
\hline & $\mathrm{b}_{2}$ & -0.14938 \\
\hline $\mathbf{2}$ & Coefficients of multiple correlation $(\mathrm{R})$ & 0.9955 \\
\hline $\mathbf{3}$ & Optimum level of sulphur $(\mathrm{kg} / \mathrm{ha})$ & 50.64077 \\
\hline $\mathbf{4}$ & Yield at optimum level $(\mathrm{kg} / \mathrm{ha})$ & 1167.76 \\
\hline $\mathbf{5}$ & Response at optimum level $(\mathrm{kg} / \mathrm{ha})$ & 392.11 \\
\hline
\end{tabular}

* Significant at $5 \%$ level of significance

Fig.1 Response of clusterbean to phosphorus fertilization

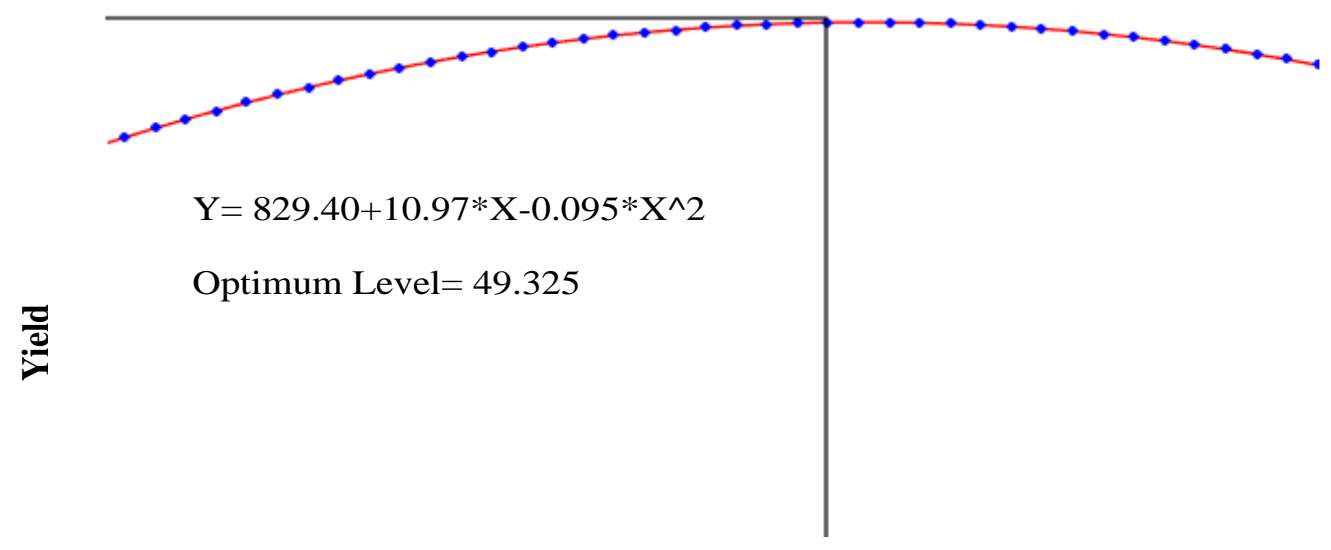

Phosphorus Levels (kg/ha) 
Fig.2 Response of clusterbean to sulphur fertilization

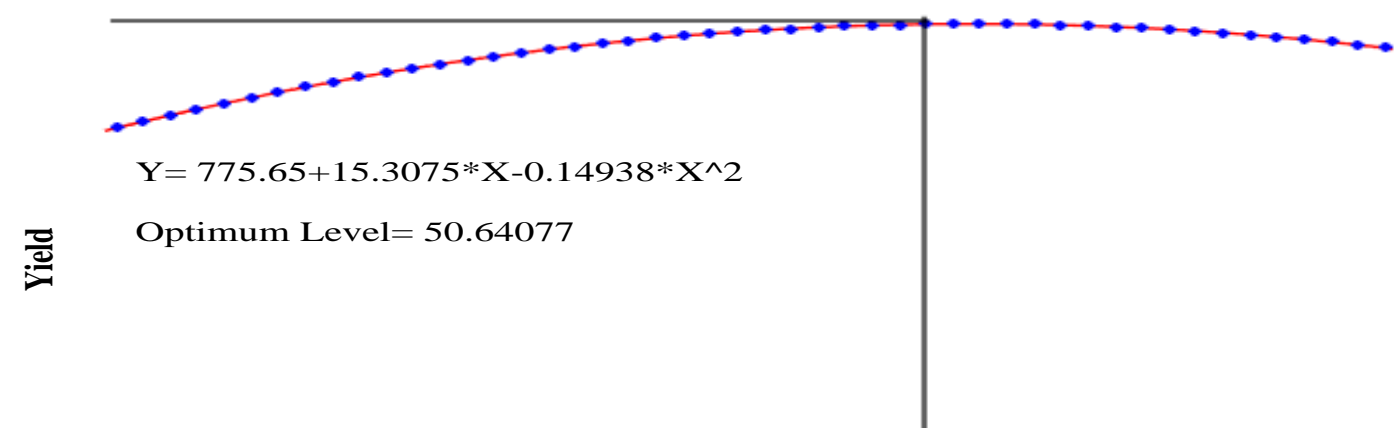

Sulphur Levels (kg/ha)

The increase in number of nodules per plant might be attributed to the optimum supply of available phosphorus to plants resulting in better development of root nodules because rhizobium in an aerobic bacteria and leghaemoglobin provide oxygen to bacteriods. Leghaemoglobin content of nodules probably increased due to application of phosphorus and it consistently made the nodules effective. Phosphorus also being the constituent of nucleic acid and different forms of protein, might have stimulated cell division resulting in increased growth of plants. Similar, results was reported by Yadav (2011) and Raiger et $a l$. , (2017) in clusterbean.

\section{Effect of phosphorus and sulphur on soil properties}

The organic carbon and available potassium content of soil after harvest of crop was not affected significantly due to the application of different levels of phosphorus and sulphur (Table-2).

\section{Available nitrogen}

Data given in table-2 showed that significantly maximum available nitrogen (128.76 $\mathrm{kg} \mathrm{ha}^{-1}$ ) was recorded under the application of $60 \mathrm{~kg} \mathrm{P}_{2} \mathrm{O}_{5} \mathrm{ha}^{-1}$ while minimum $\left(114.18 \mathrm{~kg} \mathrm{ha}^{-1}\right)$ was recorded under $\mathrm{P}_{0}$. The available nitrogen content in soil under $\mathrm{P}_{60}$ was significantly increased by $12.76,6.29$ and 3.04 percent over $\mathrm{P}_{0}, \mathrm{P}_{20}$ and $\mathrm{P}_{40}$ respectively. The available nitrogen content (128.63 $\mathrm{kg} \mathrm{ha}^{-1}$ ) in soil after harvest under $\mathrm{S}_{60}$ was significantly increased by 11.98, 6.38 and 3.20 percent over $S_{0}, S_{20}$ and $S_{40}$ respectively.

\section{Available phosphorus}

The highest available phosphorus $(20.20 \mathrm{~kg}$ $\mathrm{ha}^{-1}$ ) was recorded under $\mathrm{P}_{60}$, which was increased by 32.37, 20.38 and 11.60 percent over $\mathrm{P}_{0}, \mathrm{P}_{20}$ and $\mathrm{P}_{40}$ respectively. The significantly maximum available phosphorus $\left(19.85 \mathrm{~kg} \mathrm{ha}^{-1}\right)$ content in soil after harvest was recorded under $S_{60}$. Where as, minimum $\left(15.03 \mathrm{~kg} \mathrm{ha}^{-1}\right)$ was under $\mathrm{S}_{0}$. The increase in available phosphorus due to application of level $S_{60}$ was 32.06, 16.69 and 7.64 percent over $S_{0}, S_{20}$ and $S_{40}$ respectively.

\section{Available sulphur}

It is evident from the data given in table- 2 that available sulphur content of soil after harvest of crop increased significantly with increasing levels of phosphorus. The maximum sulphur content $\left(10.92 \mathrm{mg} \mathrm{kg}^{-1}\right)$ was recorded with the level $\mathrm{P}_{60}$, which was increased by 31.72 , 16.04 and 6.22 percent, over $\mathrm{P}_{0}, \mathrm{P}_{20}$ and $\mathrm{P}_{40}$ respectively. The application of the level $\mathrm{S}_{60}$ enhanced the available sulphur by 54.26, 17.52 and 9.51 percent as compared to $S_{0}, S_{20}$ 
and $S_{40}$ respectively. Clusterbean is legume crop and phosphorus application increase activity of soil microorganisms, more efficiency of nitrogen fixation (Yadav et al., 2014). Phosphorus also increased root nodulation which might have promoted microbial activity and thereby higher mineralization. Further, the release of organic acids and hormones due to phosphorus bacterial activity might have helped in the availability of nutrients. Similar findings were also reported by Yadav (2011), Bhatt et al., (2013) and Raiger et al., (2017). Intensive cultivation without sulphur fertilization resulted in a decline of $30-60 \%$ of sulphur content of soil when no sulphur was applied. Application of sulphur has been reported to help in lowering the soil $\mathrm{pH}$, which is the principle reason for greater availability and mobility of nutrients. Similar results were also reported by Raiger et al., (2017).

\section{Optimum dose of phosphorus}

To describe the relationship between yield of clusterbean (Y) and applied phosphorus, Since the main effect of $\mathrm{P}$ on yield of clusterbean was found significant (Table-3 and Fig-1), it was considered appropriate to establish a relationship describing the yield of clusterbean as a function of main effect of $\mathrm{P}$ fertilization. The relationship of the type $\mathrm{Y}=$ $\mathrm{b} 0+\mathrm{b} 1 \mathrm{P}+\mathrm{b} 2 \mathrm{P} 2$ describing yield as a function of $\mathrm{P}$ derived from the observed data was curvilinear and presented in table- 3 and fig-1. The estimated optimum level of phosphorus recording the predicted yield of $1139.35 \mathrm{~kg} \mathrm{ha}^{-1}$ has been worked out to be $49.31 \mathrm{~kg} \mathrm{ha}^{-1}$.

\section{Optimum dose of sulphur}

To describe the relationship between yield of clusterbean (Y) and applied sulphur, Since the main effect of $S$ on yield of clusterbean was found significant (Table-4 and Fig-2), it was considered appropriate to establish a relationship describing the yield of clusterbean as a function of main effect of $S$ fertilization. The relationship of the type $\mathrm{Y}=$ $\mathrm{b} 0+\mathrm{b} 1 \mathrm{~S}+\mathrm{b} 2 \mathrm{~S} 2$ describing yield as a function of $\mathrm{S}$ derived from the observed data was curvilinear and presented in table- 4 and Fig-2. The estimated optimum level of sulphur recording the predicted yield of $1167.76 \mathrm{~kg} \mathrm{ha}^{-1}$ have been worked out to be $50.64 \mathrm{~kg} \mathrm{ha}^{-1}$.

Based on the result of one-year experimentation, it may be concluded that total chlorophyll content at 45 DAS, total and effective root nodules per plant at flowering increased significantly with the application of $40 \mathrm{~kg} \mathrm{P}_{2} \mathrm{O}_{5} \mathrm{ha}^{-1}$ and $40 \mathrm{~kg} \mathrm{~S}^{-1}$ over lower levels. Available nitrogen, phosphorus and sulphur status in soil after harvest of clusterbean crop were recorded as significantly maximum with the application of phosphorus@60 kg ha ${ }^{-1}$ and sulphur@60 $\mathrm{kg} \mathrm{ha}^{-1}$ over rest of the treatments. Where as, optimum dose of phosphorus and sulphur for clusterbean crop were computed as $49.31 \mathrm{~kg}$ $\mathrm{P}_{2} \mathrm{O}_{5} \mathrm{ha}^{-1}$ and $50.64 \mathrm{~kg} \mathrm{~S} \mathrm{ha}^{-1}$ respectively.

\section{Acknowledgements}

We sincerely acknowledge Head, Division of Soil Science and Agricultural Chemistry, S.K.N.A.U, Jobner for providing field staff, facilities and assistance in conducting this research.

\section{References}

Arnon, D.I. 1949. Copper enzymes in isolated chloroplast. I. Polyphenol oxidase in Beta vulgaris. Plant Physiol. 24: 1-5.

Ayub, M., Nadeem, M.A., Naeem, M., Tahir, M., Tariq, M. and Ahmad, W. 2012. Effect of different levels of $\mathrm{P}$ and $\mathrm{K}$ on growth, forage yield and quantity of cluster bean [Cyamopsis tetragonoloba 
(L.) Taub]. The Journal of Animal and Plant Sciences, 22(2): 479-483.

Bhatt, P. K., Patel, P. T., Patel, B. T., Raval, C. H., Vyas, K. G. and Ali, S. 2013. Productivity, quality, nutrient content and soil fertility of summer greengram (Vigna radiata) as influenced by different levels of vermicompost and phosphorus with and without PSB. International Journal of Agricultural Sciences, 9: 659-662.

Croxton, F.C., Cowden, D.J and Klein, S. 1973. Applied general statistics 3rd Edn. Prentice Hall of India Pvt. Ltd. New Delhi.

Imsande, John 1998. Iron, sulphur and chlorophyll deficiencies: A need for an integrative approach in plant physiology. Plant Physiology103: 139144.

Kumar, S. and Kumar, S. 2013. Effect of phosphorus and sulphur on growth, yield attributes and yield of pigeonpea. Annals of Plant and Soil Research, 15(2): 138-141.
Raiger, Rekha, Kumawat, B.L., Sanwal, R.C., Kumawat, S.R. and Kumawat, S.R. 2017. Response of cluster bean [Cyamopsis tetragonoloba (L.) Taub] to $\mathrm{P}$ and $\mathrm{S}$ in Torripsamments of Rajasthan. International Journal of Current Microbiology and Applied Sciences 6(6): 2003-2008.

Tandon, H.L.S. 1986. Sulphur Research and Agricultural Production in India. 2nd ed. Fertilizer Development and Consultation Organization, New Delhi: 76.s

Yadav, B.K. 2011. Interaction effect of $P$ and $S$ on yield and quality of cluster bean in typic heplusteps. World Journal of Agricultural Sciences 7(5): 556-560.

Yadav, S.K., Patel, A.G. and Yadav, B.L. 2014. Yield, quality and soil fertility of cluster bean [Cyamopsis tetragonoloba (L.) Taub] as influenced by various row spacing and levels of phosphorus. Advance Research Journal of Crop Improvement 5(2): 101-104.

\section{How to cite this article:}

Kiran Yadav, SR. Naga, Shital Yadav and Basu Devi Yadav. 2020. Effect of Phosphorus and Sulphur on Chlorophyll, Nodulation, Soil Properties and Optimum Dose of Phosphorus and Sulphur for Clusterbean [Cyamopsis tetragonoloba (L.) Taub]. Int.J.Curr.Microbiol.App.Sci. 9(12): 1492-1499. doi: https://doi.org/10.20546/ijcmas.2020.912.177 